\title{
IMPLEMENTASI PERATURAN TENTANG MEREK DI KELURAHAN SAMBUNG JAWA MAKASSAR
}

\author{
Dwi Handayani \\ Fakultas Hukum Universitas Muslim Indonesia \\ email: dwi.handayani@umi.ac.id
}

\begin{abstract}
Makassar community is divided into sub-district, urban village, hamlet, and neighborhood unit with all its issues. One of the problems is in the Sambung Jawa, Mamajang Sub-district where there is still lack of interest and awareness to understand the importance of knowledge about the rights and obligations of a trading business (legal entity). On the other hand, there are some people who have succeeded, but are more concerned with pursuing profits to meet their needs than caring about legal issues. The solution to these problems is providing legal assistance and socialization regarding the establishment of a business entity (formerly home industry) carried out in the communities of RW 6, 7, 8, and 9 who have business activities in clothing, crafts and food industry as UMK (Micro and Small Enterprises) entrepreneurs, procedures and terms of submission of brands, as well as providing information about brand rights. The aim of this activity is to increase legal awareness and provide legal protection by continuous (periodically) mentoring both during service and afterwards. The method that used are direct meeting with servants and local officials / community leaders and discussions with partners as well as with women's organizations which resulted in an agreement that counseling and assistance will be provided by the servant. The results of the implementation of community service provide a positive value for UMK entrepreneurs with very satisfying indicators of success. Public information about brand rights was received enthusiastically by the community and provided a great motivation to increase industrial business skills so that the turnover can increase even more.
\end{abstract}

Keywords: sambung jawa, trademark, legal awareness

\begin{abstract}
ABSTRAK
Masyarakat Makassar terbagi dalam kecamatan, kelurahan, Rukun Warga dan Rukun Tetangga dengan beraneka permasalahannya. Salah satu yang mengemuka terdapat di Kelurahan Sambung Jawa Kecamatan Mamajang, dimana ditemukan masih kurangnya minat dan kesadaran untuk mengetahui dan memahami pentingnya pengetahuan tentang hak-hak dan kewajiban suatu usaha dagang/badan hukum. Di sisi lain ada sebagian masyarakat yang sudah eksis, akan tetapi lebih memikirkan mengejar keuntungan untuk memenuhi kebutuhan hidup. Prioritas solusi permasalahan yaitu pendampingan dan sosialisasi hukum tentang pembentukan suatu badan usaha (sebelumnya home industri) pada masyarakat RW 6,7,8 dan 9 yang mempunyai kegiatan usaha konveksi, kerajinan dan makanan sebagai pengusaha UMK, prosedur syarat-syarat pengajuan merek serta pemberian penyuluhan Undang-Undang tentang merek. Tujuannya adalah meningkatkan kesadaran hukum dan memberikan perlindungan hukum dengan cara pendampingan yang terus menerus (secara berkala)
\end{abstract}


baik selama pengabdian dilakukan maupun sesudahnya. Metode yang digunakan: face to face antara pengabdi dan pejabat/ tokoh, diskusi bersama mitra, organisasi perempuan dan menghasilkan kesepakatan bahwa pengabdi akan memberikan penyuluhan dan pendampingan. Hasil pelaksanaan pengabdian kepada masyarakat memberikan nilai positif bagi warga pengusaha UMK dengan indikator keberhasilan sangat memuaskan dan masyarakat menerima dengan antusias penyuluhan tentang hak merek, serta memberikan motivasi besar untuk menambah ketrampilan bidang usaha industri agar omzetnya dapat meningkat lebih besar.

Kata Kunci: sambung jawa, merek, kesadaran hukum

\section{PENDAHULUAN}

Salah satu kota terbesar di Provinsi Sulawesi Selatan adalah kota Makassar yang merupakan pusat kota terbesar di Indonesia bagian Timur dengan berbagai ragam budaya, seni dan bahasa yang tidak dapat dipandang dengan sebelah mata. Secara geografis Kelurahan Sambung Jawa terletak di Kecamatan Mamajang yang berbatasan dengan:

Sebelah Timur : Kelurahan Sambung Jawa

Sebelah Barat : Kelurahan Maccini Sombala Kecamatan Tamalate

Sebelah Utara : Kelurahan Tamparang Keke

Sebelah Selatan : Kelurahan Karang Anyar

Jarak ibu kota kecamatan 1-2 KM, jarak ibukota Kota 4.5 KM dan jarak ke ibukota propinsi adalah $6 \mathrm{KM}$. Luas wilayah Kelurahan Sambung Jawa adalah $37.39 \mathrm{Ha}$ yang terbagi menjadi 9 ORW dan 46 RT. Adapun hasil deliniasi permukiman kumuh berdasarkan SK Kumuh Walikota Makassar dan hasil verifikasi Kelurahan Sambung Jawa memiliki luas 5,16 Ha yang terdiri atas 2 RW dan 7 RT. Adapun luas wilayah masing-masing RT dapat dilihat pada gambar 1 (tabel dan peta Kawasan Kumuh Kelurahan Sambung Jawa dapat dilihat pada gambar 2 .

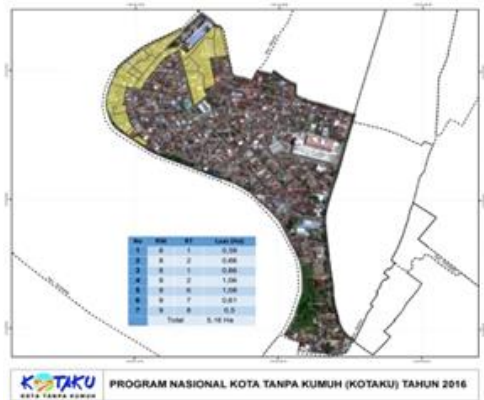

Gambar 1.

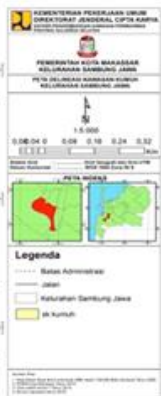

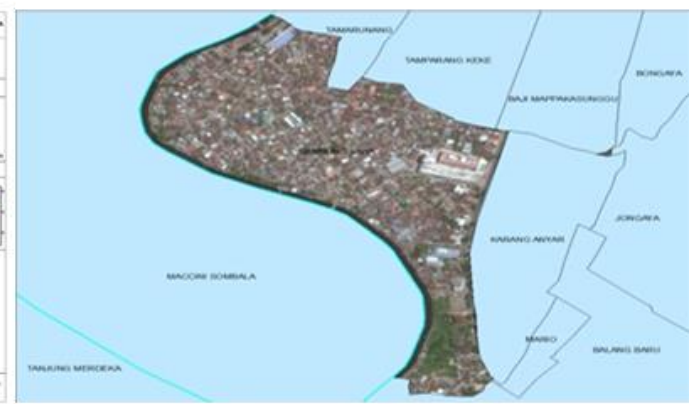

Gambar 2.

Dokumen RPLP Makassar pada program nasional kotaku (kota tanpa kumuh) tahun 2016 (data di kelurahan Sambung Jawa) 
Survey awal dilakukan dengan mengumpulkan data di kelurahan (tahun 2015) dan dapat digambarkan bahwa wilayah Sambung Jawa terbagi menjadi 9 RW dan 46 RT dengan perincian:

1. RW 01 terdiri dari $5 \mathrm{RT}$ dengan luas wilayah sebesar 6.86 ha

2. RW 02 terdiri dari $4 \mathrm{RT}$ dengan luas wilayah sebesar 3.97 ha

3. RW 03 terdiri dari $6 \mathrm{RT}$ dengan luas wilayah sebesar $4.21 \mathrm{ha}$

4. RW 04 terdiri dari 4 RT dengan luas wilayah sebesar 2.86 ha

5. RW 05 terdiri dari 4 RT dengan luas wilayah sebesar 3.44 ha

6. RW 06 terdiri dari 4 RT dengan luas wilayah sebesar 2.62 ha

7. RW 07 terdiri dari $5 \mathrm{RT}$ dengan luas wilayah sebesar 3.12 ha

8. RW 08 terdiri dari $6 \mathrm{RT}$ dengan luas wilayah sebesar 3.54 ha

9. RW 09 terdiri dari $8 \mathrm{RT}$ dengan luas wilayah sebesar 6.77 ha

Dari beberapa Rukun Warga (RW), kegiatan pengabdian akan lebih difokuskan pada RW 6 dan 7, dimana kedua RW tersebut terdapat banyak industri konveksi dan kerajinan lain yang ditekuni oleh warga masyarakat dan kaum ibu-ibu sebagai industri rumahan, namun belum mengetahui akan hakhak mereka terutama di bidang hukum, sehingga masih perlu peningkatan budaya untuk sadar hukum terutama dalam hal perlindungan hukum atas karyakaryanya di bidang kekayaan intelektual (HAKI) dan hak-hak lainnya yang berkaitan dengan pemberdayaan perempuan.

Kesadaran hukum merupakan salah satu unsur penting yang akan menentukan efektif atau tidaknya pelaksanaan hukum atau perundangundangan di dalam masyarakat, karena kesadaran hukum merupakan kesadaran atau nilai-nilai yang terdapat di dalam diri manusia tentang hukum yang ada atau tentang hukum yang diharapkan ada. Penekanannya adalah nilai-nilai tentang fungsi hukum dan bukan suatu penilaian hukum terhadap kejadian-kejadian yang konkrit dalam masyarakat yang bersangkutan. ${ }^{1}$

Menurut Soerjono Soekanto, bahwa kesadaran hukum itu merupakan persoalan nilai-nilai dan konsepsi-konsepsi abstrak yang terdapat dalam diri manusia tentang keserasian antara ketertiban dan ketentraman yang dikehendaki atau sepantasnya. ${ }^{2}$ Salah satu konsepsi kesadaran hukum adalah mengenai kebudayaan hukum yang telah banyak mempermasalah-kan kesadaran hukum yang dianggap sebagai mediator antara hukum dengan perilaku manusia, baik secara individu maupun kolektif. ${ }^{3}$ adalah:

Laica Marzuki berpendapat, bahwa pengertian kesadaran hukum "Pertama-tama bertitik tolak dari pemahaman yang memandang bahwa kesadaran hukum merupakan bagian alam kesadaran manusia. Hanya pada manusia yang berada dalam kondisi kesadaran yang sehat serta adekuat (compos menitis) dapat bertumbuh dan berkembang penghayatan kesadaran

\footnotetext{
${ }^{1}$ Soerjono Soekanto.1982. Kesadaran Hukum dan Kepatuhan Hukum.Jakarta, Rajawali Pers. Hal.152

2 Ibid. Hal. 123-124

3 Ibid. Hal.125
} 
hukum. Kesadaran hukum bukan bagian dari ketidaksadaran manusia, meskipun pertumbuhannya dipengaruhi oleh naluri hukum (rectsinstinct) yang menempati wujud bawah perasaan hukum (lagere worm van rechtsgevoed). ${ }^{4}$

Kesadaran hukum menurut Achmad Ali ada dua macam, yaitu ${ }^{5}$ :

1. Kesadaran hukum positif, identik dengan ketaatan hukum.

2. Kesadaran hukum negatif, identik dengan ketidaktaatan hukum

Selanjutnya Ahmad Ali menyatakan bahwa kesadaran hukum yang dimiliki seseorang atau warga masyarakat, belum menjamin bahwa seseorang atau warga masyarakat tersebut akan menaati suatu aturan hukum atau perundang-undangan. Sebagai contoh, seseorang yang mempunyai kesadaran hukum menyadari bahwa melanggar traffic light adalah pelanggaran hukum, dan menyadari pula bahwa hanya polisi yang berwenang untuk menangkap dan menilangnya, demikian pula orang itu dengan kesadaran hukumnya tadi belum tentu tidak melanggar lampu merah, ketika orang itu melihat tidak ada polisi di sekitar traffic light, maka orang itu karena terburu-buru untuk tidak terlambat menghadiri suatu acara penting, mungkin saja akan melanggar lampu merah, sekali lagi dengan kesadaran hukumnya, bahwa dirinya tidak akan ditilang karena tidak ada seorang polisipun disekitar itu. ${ }^{6}$

UU Nomor 20 tahun 2016 mengatur tentang Merek dan Indikasi Geografis, namun dalam hal ini kegiatan PkMD yang dilakukan di Kelurahan Sambung Jawa berupa pemberian penyuluhan hukum merek dikaitkan dengan kondisi masyarakat yang berprofesi sebagai pelaku usaha kecil dan menengah yang sudah bertahun-tahun berusaha namun belum memahami akan pentingnya mendaftarkan merek (label usaha) yang sudah digunakannya bertahun-tahun. Demikian juga bagi pelaku usaha yang belum memberikan label pada usahanya. Oleh karena itu, peningkatan kesadaran hukum harus dilakukan melalui penerangan dan penyuluhan hukum yang teratur atas dasar perencanaan yang mantap. Tujuannya adalah agar warga masyarakat memahami hukum-hukum tertentu, sesuai masalah-masalah hukum yang sedang dihadapi dalam suatu kondisi-kondisi tertentu. Penerangan dan penyuluhan hukum menjadi tugas dari kalangan hukum pada umumnya, dan khususnya mereka yang mungkin secara langsung berhubungan dengan warga masyarakat, yaitu petugas hukum.

Sehubungan dengan permasalahan yang dihadapi mitra, kegiatan pengabdian diprioritaskan pada memberikan pendampingan dan penyuluhan bidang pengetahuan hukum, sosial dan budaya/ agama.

Permasalahan yang dihadapai masyarakat secara umum terutama dari aspek sosial, budaya dan hukum, dapat diatasi dengan menumbuh

${ }^{4}$ Laica Marzuki. 1995. Siri, Bagian Kesadaran Hukum Rakyat Bugis Makassar. Hasanuddin University Pres. Hal.152

${ }^{5}$ Achmad Ali. 2012. Teori Hukum (legal Theory) dan Teori peradilan (Judicialprudence Termasuk Interpretasi Undang-Undang (Legisprudence). Jakarta:Kencana. Cet 4. Hal 298.

${ }^{6}$ Ibid. Hal.300. 
kembangkan budaya kehidupan bersama, gotong royong dan kesadaran hukum yang tinggi untuk mencapai kesejahteraan masyarakat. Dengan sosialisasi aturan hukum dan perundang-undangan serta perlindungan akan hak-hak kekayaan intelektual maka diharapkan terjadi perubahan perilaku masyarakat yang lebih baik lagi dan hasil luaran berupa produk bermerek yang sudah mendapatkan perlindungan hukum dari Departemen Hukum dan Hak Asasi Manusia (HAM). Selain itu hasil luaran lainnya berupa brosur tentang pedoman/ petunjuk cara mendaftarkan hak kekayaan intelektual (hak merek) yang akan diberikan/ dibagikan kepada masyarakat mitra untuk dipelajari dan dilaksanakan sehingga produknya yang sudah bermerek telah mendapatkan legalitas dan menjadi hak pemegang merek untuk jangka waktu tertentu.

Berdasarkan latar belakang masalah yang telah diuraikan di atas, maka yang menjadi inti permasalahan utama adalah Bagaimana meningkatkan kesadaran hukum warga masyarakat Sambung Jawa terhadap perlindungan hak-hak kekayaan intelektual (hak merek)?

\section{METODE PELAKSANAAN}

Untuk menggali, mengkaji dan menganalisis permasalahan yang ditemukan dan diperoleh di lapangan baik dengan observasi maupun pengamatan secara langsung sebelum kegiatan pengabdian dilakukan, maka dikoordinasikan terlebih dahulu dengan berkonsultasi pada Bapak Lurah Sambung Jawa sebagai pemimpin wilayah untuk mendapatkan informasi dan data akurat mengenai kondisi wilayahnya. Menurut ilmu pengetahuan, metode adalah a regular systematic plan for or way of doing something. Kata metode berasal dari istilah Yunani: methodos (meta + bodos) yang artinya cara. ${ }^{7}$

Berdasarkan data awal, metode pendekatan yang akan diterapkan dalam kegiatan pengabdian kepada masyarakat antara lain face to face antara pengabdi dan pejabat/ tokoh, diskusi bersama masyarakat/ mitra (perwakilan $\mathrm{RW}$ ), organisasi perempuan dan menghasilkan kesepakatan bahwa pengabdi akan memberikan penyuluhan dan pendampingan kepada warga RW 6 sampai 9 dan sekitarnya dengan cara mengumpulkan pada 1 tempat yang telah disepakati bersama. Tempat tersebut untuk selanjutnya dapat digunakan secara berkelanjutan apabila kegiatan pengabdian telah selesai. Selain itu bagi ibu-ibu yang tergabung dalam Majelis Taklim dapat diberikan penyuluhan tentang KDRT dan undang-undang tentang perlindungan anak untuk meningkatkan wawasan bidang hukum, sedang terhadap anak-anak sekolah tingkat SMA/SMK dapat diberikan penyuluhan tentang bahaya narkoba, bahaya merokok dan kenakalan remaja.

Pengabdian ini menitikberatkan pada subyek seluruh masyarakat kelurahan Sambung Jawa dengan segala aktivitasnya yang berkaitan dengan

\footnotetext{
${ }^{7}$ Gumilar Rusliwa Somantri, 2005, "Memahami metode kualitatif", Jurnal Makara Sosial Humaniora, Vol.9, No.2 Desember 2005, h.57-65
} 
sasaran yang akan dicapai. Penentuan sampel didasarkan pada tujuan tertentu (purposive sampling)

\section{HASIL DAN PEMBAHASAN}

\section{Bentuk, Waktu dan Tempat Kegiatan}

Sebelumnya akan diuraikan terlebih dahulu kegiatan pelaksanaan PkMD yang dilakukan di beberapa Rukun Warga (RW), dan hasil tinjauan lapangan ternyata kegiatan pengabdian masyarakat lebih efektif dilaksanakan dengan mengumpulkan perwakilan dari beberapa RW yang mempunyai kegiatan Usaha Kecil Menengah (UKM) yaitu usaha industri konveksi, kerajinan, makanan kecil dan usaha lain yang ditekuni oleh warga masyarakat dan kaum ibu-ibu sebagai industri rumahan, namun belum mengetahui akan hak-hak mereka terutama di bidang hukum, sehingga masih perlu peningkatan budaya untuk sadar hukum terutama dalam hal perlindungan hukum atas karya-karyanya di bidang kekayaan intelektual (HAKI) dan hak-hak lainnya yang berkaitan dengan pemberdayaan perempuan. Salah satu hak intelektual hasil olah pikir para warga masyarakat Sambung Jawa yang menjadi sasaran kegiatan pengabdian adalah Hak Merek.

Budaya sadar hukum sangat tergantung pada adanya niat dan kemauan untuk merubah paradigama lebih maju dan berkembang. Kesadaran hukum merupakan salah satu unsur penting yang akan menentukan efektif atau tidaknya pelaksanaan hukum atau perundangundangan di dalam masyarakat, karena kesadaran hukum merupakan kesadaran atau nilai-nilai yang terdapat di dalam diri manusia tentang hukum yang ada atau tentang hukum yang diharapkan ada. Penekanannya adalah nilai-nilai tentang fungsi hukum dan bukan suatu penilaian hukum terhadap kejadian-kejadian yang konkrit dalam masyarakat yang bersangkutan. $^{8}$

Kondisi demikian yang akan dicapai oleh dosen pengabdi setelah warga masyarakat Sambung Jawa mendapatkan pendampingan dan penyuluhan tentang kesadaran akan pentingnya hukum sehingga pola pikir mereka dapat meningkat dan berubah dengan bertambahnya pengetahuan hukum merek yang diberikan selama pengabdian. Sebagai pelaku usaha mikro, masyarakat terus dipacu, diberi semangat dan diharapkan dapat meningkatkan omzet usahanya sehingga label dagang yang sudah ada namun belum terdaftar, segera dapat didaftarkan ke Direktorat Jenderal HKI Kementrian Hukum dan HAM dengan membawa persyaratan yang sudah ditentukan berdasarkan undang-undang yaitu UU Nomor 20 Tahun 2016 tentang Merek dan Indikasi Geografis.

${ }^{8}$ Soerjono Soekanto.1982. Kesadaran Hukum dan Kepatuhan Hukum.Jakarta, Rajawali Pers. Hal.152 
Sebelum penyuluhan hak merek kepada warga masyarakat, kepada ketua RW dan tokoh masyarakat masing-masing diberikan pengarahan dahulu tentang materi penyuluhan yang akan diberikan. Bahwa dalam memberikan penyuluhan, pengabdi merujuk pada pengertian merek menurut Philip Kotler dalam Freddy Rangkuti (2008: 35) yaitu: "is a name, term, sign, symbol or design or combination of them, intended to identify the goods or services of one seller of group of sellers and differentiate them from those of competitors". ${ }^{9}$ Selain itu merek (brand) juga berarti nama atau simbol yang diasosiasikan dengan produk jasa dan menimbulkan arti psikologis atau asosiasi. ${ }^{10}$

Secara singkat kegiatan-kegiatan pengabdian kepada masyarakat di kelurahan Sambung Jawa dapat disajikan dalam tabel berikut ini:

Table 1.

Kegiatan pengabdian kepada masyarakat di kelurahan Sambung Jawa

\begin{tabular}{|c|c|c|c|c|}
\hline No & Judul & Tahun & $\begin{array}{l}\text { Tempat } \\
\text { Penerapan }\end{array}$ & $\begin{array}{c}\text { Respon } \\
\text { Masyarakat }\end{array}$ \\
\hline 1. & $\begin{array}{l}\text { Pendampingan/penyuluhan } \\
\text { hak merek pada Ibu-ibu } \\
\text { perajin UMK kerajinan } \\
\text { Eceng Gondok. }\end{array}$ & $\begin{array}{l}7 \\
\text { Januari } \\
2019\end{array}$ & $\begin{array}{l}\text { Ibu Hajjah } \\
\text { Wahdah }\end{array}$ & $\begin{array}{l}\text { Positip dan sangat } \\
\text { antusias menerima } \\
\text { penyuluhan hak } \\
\text { merek. }\end{array}$ \\
\hline 2. & $\begin{array}{l}\text { Penyuluhan hak merek } \\
\text { pada semua warga UMK } \\
\text { perwakilan } 9 \text { RW } \\
\text { Kelurahan Sambung Jawa. }\end{array}$ & $\begin{array}{l}12 \\
\text { Januari } \\
2019\end{array}$ & sda & $\begin{array}{l}\text { Positip dan } \\
\text { mengharapkan agar } \\
\text { setelah penyuluhan } \\
\text { tetap dibantu dan } \\
\text { dipantau } \\
\text { kelanjutannya. }\end{array}$ \\
\hline
\end{tabular}

\section{Peserta/Partisipan Masyarakat Sasaran}

Pertama: Yang menjadi sasaran pengabdian adalah masyarakat RW 5,6,7,8 dan 9 kelurahan Sambung Jawa yang mempunyai kegiatan usaha kecil/ mikro dan menengah (UKM) dari berbagai jenis usaha antara lain makanan, kerajinan tangan dan konveksi yang ada di lokasi. Sasaran akhirnya berfokus di RW 8 terlebih dahulu di mana terdapat sentral pembuatan kerajinan tangan dari bahan eceng gondok di rumah Ibu Hajjah Wahdah. Masyarakat pada RW 8 adalah kampung pemukiman padat dengan kondisi jalan sempit, masuk lorong-lorong dan ditemukan tempat pusat kegiatan di Jalan Tanjung Palette Nomor 40 RT 5 RW 8. Anggota perkumpulan ini adalah ibu-ibu perwakilan 9 RW yang setiap hari Senin sampai Kamis mengadakan kegiatan membuat kerajinan tangan dari

9 Freddy Rangkuti.2008. The Powers of Brand: Teknik mengelola Brand Equity dan Strategi Pengembangan Merek.Cet.III.Jakarta.Gramedia Pustaka Utama. Hal.35.

${ }^{10}$ Kasiyan dan Sri Atun. 2014. Pengembangan Desain Merek Produk Kerajinan bagi UKM untuk Percepatan Perolehan HKI di Kulonprogo. Laporan PPM Lembaga Penelitian dan Pengabdian kepada Masyarakat UNY. Yogyakarta. Hal. 4. 
bahan eceng gondok berupa tempat tisu, tas, sandal dan lain-lain. Hasil kerajinan ini belum berlabel/ bermerek/ sudah ada yang diberi label tetapi belum terdaftar, sehingga dosen pengabdi memberikan pendampingan dan penyuluhan disela-sela mereka berkegiatan tentang pentingnya pendaftaran merek. Peserta yang hadir kadang berjumlah banyak terkadang juga sedikit, namun mereka tetap antusias dan semangat untuk membuat kerajinan tersebut apalagi kalau ada pesanan. Pemasarannya masih bersifat lokal dari mulut ke mulut, namun sudah ada rencana untuk dipasarkan melalui on line meskipun baru sebatas industri makanan kecil. Oleh karena pentingnya penyuluhan hukum tentang perundang-undangan lainnya yang berkaitan dengan kondisi lapangan (banyak ibu-ibu sebagai peserta), maka di sela-sela waktu lainnya pada tempat yang sama, dosen pengabdi berkesempatan juga memberikan penyuluhan tentang pentingnya Undang-undang Perlindungan Anak (UU Nomor 23 Tahun 2002 jo UU Nomor 35 Tahun 2014), UU Nomor 23 Tahun 2004 tentang Penghapusan Kekerasan Dalam Rumah Tangga (KDRT) serta pengetahuan tentang hukum perusahaan atau bentuk badan usaha.

Kedua: Sasaran peserta pengabdian menjadi diperluas berdasarkan masukan-masukan dari ketua-ketua RW dan lbu Ketua UMK perajin eceng gondok Hajjah Wahdah yang selanjutnya disepakati yang ikut penyuluhan hak merek adalah perwakilan dari 9 RW kelurahan Sambung Jawa kurang lebih 40-50 orang yang dihadiri oleh Sekertaris Camat Mamajang Bapak.Rendra, SE. sebagai pelaksana harian dari lurah Sambung Jawa yang sebelumnya dijabat oleh Bpk. Andi Irdan Pandita, S.STP, M.Si. Penyuluhan dilaksanakan hari Sabtu tanggal 12 Januari 2019 jam 16.00 sampai selesai. Masyarakat sangat antusias menyimak dan mengikuti penyuluhan tentang merek ini sampai selesai, dan banyak pertanyaan yang diajukan serta untuk selanjutnya bermohon agar minta didampingi untuk pengurusannya di Kementrian Hukum dan Hak Asasi Manusia pada unit pelayanan HKI. Masyarakat memohon agar setelah penyuluhan, dosen pengabdi dapat membantu untuk proses pendaftaran merek. Kami Tim bersedia untuk membantu mereka dengan cara kolektif supaya pengurusannya lebih mudah dengan melampirkan syarat-syarat yang sudah ditentukan dalam brosur atau pedoman yang sudah kami bagikan kepada mereka. 


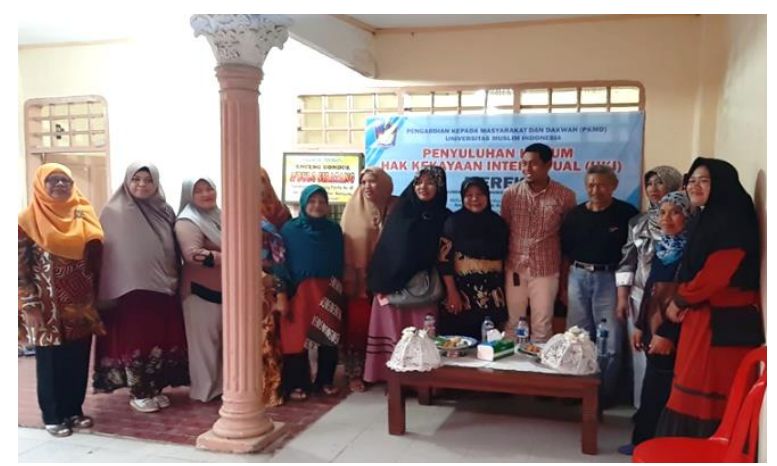

Gambar 3. Sebagian warga perwakilan 9 RW kelurahan Sambung Jawa setelah mendapat penyuluhan dari penyuluh Dwi Handayani (gambar paling kanan) tentang hukum merek, bergambar bersama bapak sekertaris camat Kecamatan Mamajang dan ketua RW 08. (dokumentasi pribadi tahun 2019)

\section{Tinjauan Hasil yang Dicapai}

Berdasarkan hasil tinjauan sementara melalui kelurahan, masyarakat sasar sangat berminat untuk mengurus merek terdaftar untuk hasil usahanya, terlebih ada dispensasi/ keringanan biaya untuk UKM menurut syarat-syarat yang telah ditentukan oleh Kemenkumham Ditjen HKI. Berdasarkan pengamatan, rata-rata hasil yang dicapai dari penyuluhan hak merek ini sangat memuaskan warga, khususnya para pengusaha UMK. Di sisi lain masih banyak pengusaha UMK yang belum mendapatkan kesempatan untuk mengikuti penyuluhan berharap agar mereka di kemudian hari dapat dipanggil untuk diberikan kesempatan mengikuti penyuluhan tentang hak merek sehingga hak-haknya dapat terlindungi oleh hokum.

\section{Evaluasi Kegiatan}

- Berkaitan dengan proses kegiatan yang sudah berjalan dimana wilayah sasar sudah pernah dilakukan penyuluhan, maka program PkMD ini perlu dilanjutkan secara berkesinambungan dan terus menerus agar hasilnya tercapai lebih maksimal.

- Perlu dianggarkan dana untuk wilayah sasar yang belum dilakukan penyuluhan dan pendampingan terutama masyarakat UKM, agar hasil produknya dilindungi oleh hukum dengan label/ merek dagang yang terdaftar menurut undang-undang.

- Agar proses pengurusan surat keterangan yang menerangkan UKM, dipermudah dan diperlancar sebagai salah satu syarat untuk pendaftaran hak merek dan kalau bisa biayanya digratiskan sehingga masyarakat/ pengusaha sasar golongan menengah dan kecil dapat menikmati kemudahan yang diberikan oleh pemerintah. Hal ini tidak terlepas dari koordinasi dan kerja sama antara Kementrian perindustrian dan Usaha Kecil Menengah (UKM); Pemda kabupaten/ kota dan Kementrian Hukum dan Hak Asasi Manusia (HAM). 


\section{Permasalahan dan Hambatan}

- Pihak UMK sendiri mengalami kesulitan dalam hal modal untuk pengembangan usahanya/ meningkatkan produk usahanya sampai mencapai standar usaha kecil dengan omzet minimal antara 300 juta sampai dengan 2,5 milyar per tahun. Dengan standar tersebut seorang pengusaha UMK dapat mengajukan permohonan sebagai UMK guna mendapatkan SK dari Dinas Perindustrian dan UMK. Syarat inilah yang nanti dapat digunakan sebagai salah satu syarat untuk mendaftarkan merek/ logo usahanya pada Kemenkumham dengan biaya yang lebih ringan dibandingkan biaya mengurus secara umum/ swasta. Dengan pendaftaran merek, pemilik merek/logo yang telah terdaftar akan dilindungi oleh undang-undang (UU Nomor 20 Tahun 2016).

- Sulit untuk mendapatkan kesepakatan berkaitan dengan waktu dan tempat penyuluhan bagi sebagian pengusaha UMK karena kesibukan masing-masing yang setiap harinya dari pagi sampai petang berkegiatan menjalankan usahanya, bahkan sampai tengah malam jika ordernya banyak. Oleh karena itu perlu menunjuk satu tokoh masyarakat yang disegani (ketua UMK) untuk memfasilitasi.

\section{KESIMPULAN}

Berdasarkan data-data hasil kegiatan pengabdian dosen yang telah diuraikan pada bab sebelumnya, maka dapat disimpulkan bahwa untuk meningkatkan kesadaran hukum warga masyarakat Kelurahan Sambung Jawa, maka telah dilaksanakan kegiatan pengabdian kepada masyarakat dan dakwah berupa penyuluhan hukum antara lain hukum merek, hukum perusahaan. Kegiatan telah berhasil dengan memuaskan meskipun masih belum maksimal. Keberhasilan ini dapat diukur dari antusias, minat dan motivasi yang tinggi dari warga masyarakat Sambung Jawa atau mitra sasar yang mempunyai kegiatan usaha (pengusaha UMK) untuk mengikuti penyuluhan hukum/ hak merek dengan jumlah peserta mencapai kurang lebih 47 orang. Belum maksimalnya kegiatan ini nampak dari keinginan warga masyarakat lain yang tidak diundang untuk mengikuti penyuluhan, namun sangat antusias untuk mengikuti kegiatan ini. Oleh karena itu, maka kegiatan ini sebaiknya dilakukan secara berkesinambungan/ berkala dengan karakteristik pengusaha UKM yang sejenis sehingga lebih mudah diketahui efektif tidaknya keberlanjutan program PkMD.

\section{DAFTAR RUJUKAN}

\section{Buku:}

Achmad Ali. (2012). Teori Hukum (legal Theory) dan Teori peradilan (Judicialprudence Termasuk Interpretasi Undang-Undang (Legisprudence). Jakarta:Kencana. Cet 4. 
Freddy Rangkuti. (2008). The Powers of Brand: Teknik mengelola Brand Equity dan Strategi Pengembangan Merek. Cet. III.Jakarta. Gramedia Pustaka Utama.

Laica Marzuki. (1995). Siri, Bagian Kesadaran Hukum Rakyat Bugis Makassar. Hasanuddin University Pres.

NN. (2015). Gambaran Umum (Rona) wilayah Kelurahan Sambung Jawa, Dokumen Rencana Penataan Lingkungan Permukiman, Makassar (RPLP).

Soerjono Soekanto.(1982). Kesadaran Hukum dan Kepatuhan Hukum.Jakarta, Rajawali Pers.

Jurnal/Laporan:

Gumilar Rusliwa, Somantri, (2005), "Memahami metode kualitatif", Jurnal Makara Sosial Humaniora, Vol.9, No.2 Desember 2005.

Kasiyan \& Sri Atun. (2014). Pengembangan Desain Merek Produk Kerajinan bagi UKM untuk Percepatan Perolehan HKI di Kulonprogo. Laporan PPM Lembaga Penelitian dan Pengabdian kepada Masyarakat UNY. Yogyakarta.

\section{Perundang-undangan:}

UU Nomor 23 Tahun 2004 tentang Penghapusan Kekerasan Dalam Rumah Tangga (KDRT).

Undang-Undang Nomor 35 Tahun 2009 tentang Narkotika.

Undang-Undang Nomor 20 Tahun 2016 tentang Merek dan Indikasi Geografis. UU Nomor 23 Tahun 2002 jo UU Nomor 35 Tahun 2014 tentang Perlindungan Anak. 